\title{
Territories, Corridors, and Networks: A Biological Model for the Premodern State
}

\author{
MONICA L. SMITH \\ Department of Anthropology, University of California-Los Angeles, Los Angeles, California 90095-1553
}

Received July 13, 2005; revised September 3, 2006; accepted September 3, 2006

\begin{abstract}
When depicted on maps as homogenous territorial wholes, ancient states are visually summarized as static entities in a way that conceals the highly fluid dynamics of polity formation, maintenance, and growth. Models derived from studies of animal behavior show that "territory" does not consist of an undifferentiated use of the landscape. Instead, the concept of territory can be parsed into a series of resource-rich nodes linked by corridors of access, surrounded by unutilized regions and boundaries marked at points of competition. Ancient human groups also can be analyzed as having perceived and occupied landscapes through strategies of flexible networks in which nodes and corridors were surrounded by unutilized spaces around which boundaries were selectively identified and defended. This strategy is identifiable in human social groups at different levels of complexity ranging from hunter-gatherers through ancient chiefdoms and states. (0) 2007 Wiley Periodicals, Inc. Complexity 12: $28-35,2007$
\end{abstract}

Key Words: territory; networks; corridors; state formation; boundaries; maps; warfare; archaeology

\section{INTRODUCTION}

W hen represented on maps, ancient states and empires generally are depicted as homogenous wholes: neatly bounded and color-coded, they are meant to be understood as analogous to the modern world's division of the globe into precise, nonoverlapping spaces. These depictions unwittingly guide our expectations for ancient human behavior, because the presence of boundaries and the application of a shaded overlay imply a certain level of cultural cohesion, administrative effectiveness, and bureaucratic control.

Correspondence to: Monica L. Smith, E-mail: smith@ucla.edu
New assessments of political formations, however, show that single-criterion boundaries are insufficient for understanding the organization and impact of political claims on territory even for modern states [1-4]. Delimitations based on language, culture, political influence, and economic impacts mean that "boundaries" can be drawn in many different ways for any single polity (e.g., [5-10]). Similarly, the cartographic crystallization of ancient states in a single territorial map hides a number of realities in the process of state formation and development: overlapping and contested frontiers; gaps between political centers; fluctuating levels of raw materials and population; changing relationships between and among hierarchical levels; and differential levels of investment from the center to the hinterlands 
[11]. Rather than using a bounded territory model to show states at their maximal extent, our understanding of ancient as well as modern states can be improved through the use of a network model of analysis and depiction.

The analysis of networks created and utilized by both simple and complex animals provides us with alternative ways of mapping human landscape use. Animal studies show that territories are not used as whole entities, but instead consist of networks of corridors that link nodes of resource interest. The boundaries around those resource zones are highly selective, with boundary maintenance occurring as a low proportion of energy investment. Analyzing "territory" as a combination of nodal links and selective boundary maintenance results in a model of landscape use that is highly flexible and energy-efficient, with significant implications for both the acquisition and defense of resources.

\section{A BIOLOGICAL MODEL OF TERRITORIES, CORRIDORS, AND NETWORKS}

One of the challenges to understanding the premodern past is that our source information is fragmentary, limited, and often contradictory. Texts are available for only the past 5000 years and often represent elites' ideals about the size and control of political territories rather than reports of actual activities. Archaeological remains, although more democratic and ubiquitous, are subject to considerable interpretations: for example, do nonlocal goods found on an archaeological site constitute evidence for trade, domination, or alliance? To address compelling questions of human interaction in the past, archaeologists construct models to which the physical evidence can be applied.

Biology and the physical sciences have provided numerous starting points for archaeological model building, including chaos theory [12], the concept of self-organizing systems [13], and the shift from quantitative to qualitative changes (e.g., from chemistry [14]). Model building based on natural science observations do not imply that humans are mechanistic or that they are incapable of cultural adaptations, but such models do "introduce and highlight methodological and theoretical issues that are common and intelligible to both the natural and social sciences" [15, p 351]. Examples of natural-science analogies to human social groupings include Cherry's [16] comparison of the trajectory of state growth with that of a bacterial colony and Johnson's [17] call for the application of gravity models derived from Newtonian physics to human societies. In the model developed below, animal behavior in landscapes is utilized to understand two components of the territory concept: resources and boundaries.

\section{FIGURE 1}

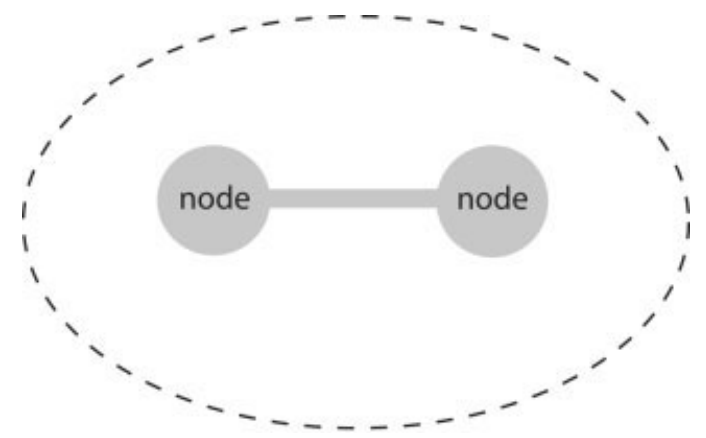

Resource nodes are accessed by corridors.

\section{Dynamic Networks among Nonhuman Species: Resources and Competition}

Animals preferentially occupy habitats that are favorable to the needs of their species. Because resources are not evenly distributed in nature, habitats typically consist of a multitude of resource zones [18, 19]. These characteristics have been observed through numerous studies of synchronic and diachronic resource use in species that make use of large areas, such as mammals and birds (e.g., [20-25]. Many of these mobile species exploit a variety of different habitats simultaneously, moving from place to place to obtain resources such as prey, shelter, water, and other members of their species for mating. The more complex the animal (generally corresponding to higher up the food chain), the larger the space habitually occupied by the animal in the course of these movements. The resultant use-area can be calculated as a matter of simple energetics, such that each progressively larger coverage incurs a number of costs along with potential benefits. As Carr and Macdonald observe [26, pp 1546-1547], a larger area can provide animals with increased food security, but at the expense of higher travel and defense costs, reduced per-area landscape familiarity, and "the social and kinship consequences of interacting with a larger group membership." A larger use area also requires greater time spent in information gathering and information processing to learn about the location of resources [27].

In practical terms, animals' use of their "territory" can be abstracted to specific resource patches and the means to move among them (Figures 1 and 2). Movement requires the use of pathways, or corridors, by which animals navigate among loci of investment $[24,28]$. Corridors can be naturally defined, for example, stream courses that enable plant and animal species to have a long linear distribution or mountain chains that provide a sustained distribution of elevated topography. Corridors also can be created by humans seeking to mitigate habitat loss, an action that con- 


\section{FIEURE 2}

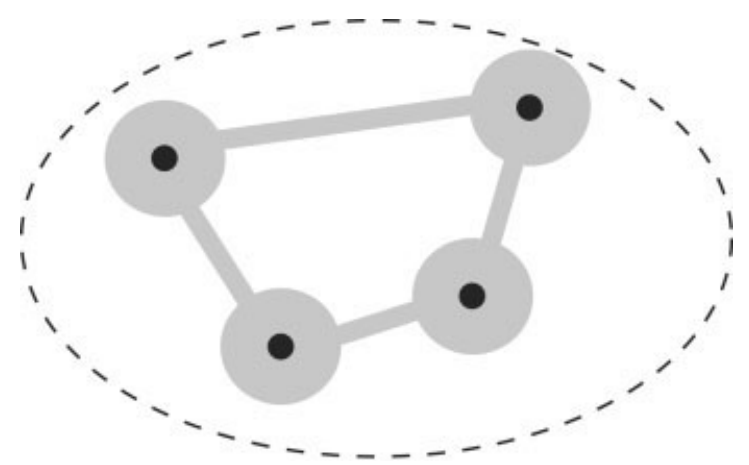

Animal "territory" can be parsed as a set of nodes and corridors bounded by a porous and shifting boundary.

stitutes a major, if somewhat controversial, movement in contemporary conservation studies; see [28-34]. Corridors may include some disadvantages, because they may not contain any of the animal's needed resources and may even incur significant costs in the form of predation or energy depletion. Nonetheless, the use of corridors is a highly efficient way for animals to access desired resources, even when those lines of access are sub-par. As Palomares [23, p 9] notes in his study of the Iberian lynx, "corridors connecting reserves do not have to be prime habitats; they can even support moderate habitat degradation."

There is a temporal as well as spatial component of resource acquisition in natural landscapes. Individuals may utilize resources differently at different points of the life cycle (e.g., juvenile dispersal or mating). The landscape itself changes through seasonal variations in resource availability as well as occasional catastrophic shifts due to tectonics, volcanic activity, or floods. These temporal and spatial components are the background for dynamic interactions between individuals, both when individuals encounter members of their own species and when they interact with members of different species. As a result, "territory" is conditioned by interactions as much as by the presence or absence of resources [19] and can be defined as an "area within the home range occupied more or less exclusively by an animal or group of animals of the same species, and held through overt defense, display or advertisement" [35, p 246]. The resultant interaction, often in the form of direct or indirect competition, can occur between members of the same species or among different species when individuals or groups seek to use the same resources [19].

In the animal realm, competition is ever-present but expressed and mitigated in a number of ways. Territories are often marked in a way that enables limits to be established so that actual conflict can be avoided (e.g., [19, 20, 27, 36]). Members of some species can use the same resources at different times so as to reduce the potential for encounters $[25$,
26]. Other strategies include the use of plumage, scent marking and call displays to advertise an individual's presence and stave off conflict [20, 22, 24, 37-42]. Animals are selective in the location of even these low-energy displays, because they can calibrate their output to the perceived strength of the neighbor. In their study of the African antelope Ourebia ourebi, Brashares and Arcese [20] observed that male marking of borders was more intense at points where neighboring groups had multiple males, rather than being correlated with overall territory size or the number of females in adjacent groups. The effect of selective intensity also meant that "marks were rarely placed in areas not immediately adjacent to another territory... [and] males rarely marked in areas adjacent to undefended habitat" [20, p 7].

Competition also includes deliberate contact, of course, but again there are a number of ways in which this contact is expressed. For example, conspecifics settling into a new area may purposefully place themselves immediately adjacent to a known competitor to avoid leaving a buffer zone that a rival could wedge its way into [18, 27]. First encounters can also condition subsequent interactions between neighbors, as Stamps [27] noted in her long-term research on Anolis aeneus lizards (see also [36-40]). Three important observations about conflict can be abstracted from this study. First, individuals with characteristics that would appear to be disadvantageous (such as smaller size) seek to postpone initial encounters with their neighbors in order to gain familiarity with the landscape that provides them with an information-based advantage in fights; further, even animals that are constantly at a disadvantage eventually gain habitat area because they keep returning to the area until the dominant neighbor loses interest. Second, Stamps and Krishnan [38] criticize game theory approaches for assuming that a fight is expensive relative to low-energy chases, because fights seem to definitively establish the relationship between two neighbors. What appears to be a costly initial investment in boundary defense may thus prevent a longrunning drain on energy expended in chases or displays. Finally, they observed that the timing and response to boundary challenges is determined by both parties: "The dominant member of a dyad may control the location, number, and vigour of social interactions, but the subordinate decides how it will respond to those interactions" [38, p 1398].

In sum, animals use landscapes in specific ways. They seek resources by moving along corridors of access and limit their territorial defense mechanisms to two locations: places in which there are particular resources such as food or mates [26, p 1540] and the specific perimeter at which competition is the most pronounced and conflict is most likely. As a result, not all of the home range identified as belonging to an individual or group is used or defended at an equal level of intensity. 


\section{Dynamic Networks for Simple and Complex Human Societies}

Like wildlife biologists, archaeologists studying complex societies and their territories do so through the analysis of three different things: movement, stasis, and temporality. The biological node-and-corridor model of landscape use and behavior can be applied to human social groups of all sizes, ranging from individual social networks, pastoral groups, and village agricultural societies, to larger configurations such as ranked societies (chiefdoms) and states.

Starting at the level of a single individual, network models depict the considerable amount of flexibility evident in the creation of both connections and boundaries. The study of individuals' social networks is predicated on both the ideological and practical aspects of interaction in which "from the moment of birth the individual is never merely a member of the family into which he or she is born; the individual is also a member of the larger collectivity into which he or she is born" [43, p 151]. Individuals' networks were first analyzed by sociologists in the 1930s seeking to understand how social groups are integrated and the extent to which individual actions contribute to social dynamics (e.g., [44, 45]). By mapping the frequency and number of interactions, these researchers showed that structures of communication are disproportionately concentrated on certain individuals whose influence can extend to numerous spheres (economic, political, and social), and that some individuals are relatively isolated from widespread contact. The recognition of social "empty space" and flexible, situational networks has resulted in greater understanding of cooperative behavior and game theory (e.g., [46]) as well as the now-famous "small world" experiments ([47]; see also [48]).

Moving beyond individuals, the use of extensive physical terrain by mobile groups provides a distinct view of the way in which humans conceptualize landscapes as discrete packets of resources, rather than as homogenous territorial wholes. Responding to the observations of modern foragers, Johnson [17] noted that hunter-gatherer settlement systems are governed by their movements across the landscape to capture diverse and spatially discontinuous resources. Similarly, transhumant pastoralists' movement around the landscape is such that "Usufruct systems typically display an unbounded, point-centred spatial pattern (nucleated) with rangeland access governed by grazing radii around tenured points (ponds, wells, encampments) rather than bounded range territories" [49, p 108]. Resources are categorized not only by availability of fodder and water, but by the quality, abundance, and timing of access, resulting in a highly flexible use of landscape that varies from year to year. Because the fluctuation in resource quality also affects the amount of competition for access, the maintenance of boundaries is impractical. Because "all herders are 'outsiders' during a portion of the yearly cycle” [49, p 97], pastoralists must constantly negotiate with their competitors, resulting in interactions characterized by mobility, reciprocity, and flexibility [50].

Even among sedentary agricultural groups, the concept of flexible access and porous boundaries prevails. Access to land may be divided between outright possession and various types of use, in which genealogy or patron-client relationships can determine who will plant, harvest, glean, or traverse land parcels [51]. In addition to fixed-place property, agriculturalists perceive that access to labor, working capital, knowledge, and social relations are part of their productive resources [52], all of which are distributed unevenly through both space and time. Individuals may possess or utilize a number of noncontiguous parcels, whereas disputes over access to soil, plants, or water can result in some otherwise-viable land parcels remaining underutilized or even "empty." Complex hunter-gatherers, who are also sedentary but utilize diverse landscapes, similarly manage resource access and boundaries through continuous negotiations in which access to resources and the boundaries maintained among groups are subject to a variety of parameters [53, 54].

Coalitions of social groups in increasingly large landscapes of contact and political cohesion further demonstrate the utility of the network concept of resource access and boundary definition. Although the idea of borders and boundaries has sometimes been projected as a component of chiefdoms (e.g., [55, p 151]), the presence of firm boundaries is relatively rare in practice. Instead, the political, social, and economic links sustained by chiefdoms are seen to render them both diverse and fragile, consolidating "in one place, only to disintegrate a little later and then reappear elsewhere" [56, p 13]. Dodgshon [57, p 108] describes Scottish Highland chiefdoms of the 15-18th centuries AD as being segmented entities, in which "petty chiefdoms jostled each other in expectation of being at the centre of the next eruption of power." Competition among local chiefs is fueled by their management of resources such as labor, agricultural products, and exotica, such that regional hierarchies "emerge through the temporary resolution of this conflict" [58, p 644, emphasis added]. As a result, spiky networks of alliance, resource acquisition, and labor investment that allow for the mapping of successive shifts is likely to be a much more accurate mode of analysis for chiefdomlevel societies.

The growth of human societies to the largest category of complexity, states and empires, is predicated on the same mechanisms of effective control, access, and defense (for definitions and discussion of premodern states, see [59$62])$. Because states "usually exist in networks of states" [63, p 385], an examination of the function of corridors and nodes provides a more precise sequential means by which the growth, maintenance, and collapse of individual states can be observed. State growth through the conquest and absorption of another state's domains is not a matter of one homogeneous "blob" annexing another blob, but control of 


\section{FIGURE 3}

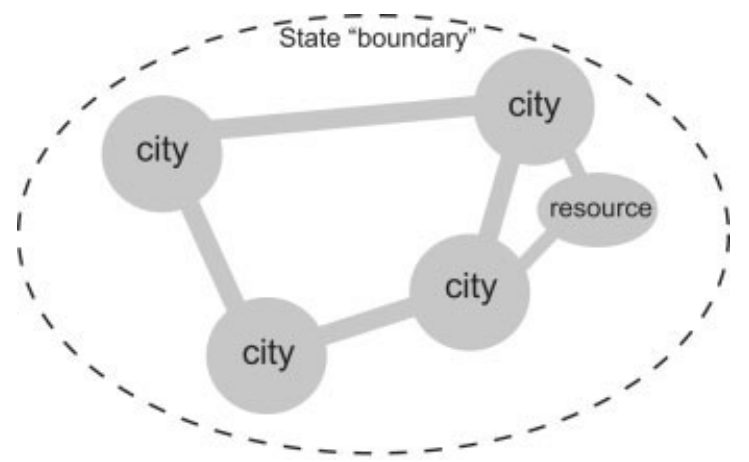

State territory mapped as a series of nodes (population centers and resources) joined through corridors (roads, canals, rivers) and surrounded by a porous and shifting boundary defined by internal and external interactions.

critical corridors and nodes that then knit the two systems together. Seen this way, state growth (especially in areas of rapid turnover such as ancient Mesopotamia or medieval India) can be assessed as a relatively low-cost operation in a nodes-and-corridor model rather than the doubling or tripling of land area (with its attendant problems and managerial needs) implied in the territorial blob model. Historical texts that often accompany this transition lead archaeologists to regard the state as a stable construct in which territories are consolidated through firm boundaries. However, the rapidity of state growth, consolidation, and fragmentation is equivalent to the processes seen in polities at the size of chiefdoms and smaller. States' use of the same adaptive strategies for resource acquisition and selective boundary maintenance indicate that the transition from chiefdoms to states is thus largely a definitional problem (cf. [64, p 4]) rather than a qualitative change.

The adoption of a node-and-corridor model also illustrates how states grow to a large size utilizing networks that are strategically integrated to control nodes across regions (Figure 3). As Spencer [61, p 235] has observed, complex societies with higher populations "tend to have an advantage over smaller, simpler ones in most competitive situations." This proposition is mirrored in Gehring and Swihart's [65] observations of mammalian predators and why "larger is better" for adaptation to changing circumstances: animals having a high diet breadth and high mobility within a varied landscape are correspondingly better able to adapt to changing landscapes brought about by habitat fragmentation or environmental shifts. This serves as an apt metaphor for the way in which regions such as Mesopotamia, the Valley of Mexico, and Egypt continually supported states even though states are the most expensive form of social management. With bureaucratic and administrative mech- anisms developed to administer a variety of resources and people, states are analogous to those "matrix tolerant" (cf. [65, p 287]) animals that can adapt to changed circumstances and new stresses such as competition from other states and environmental catastrophes.

In the process of polity formation and expansion, a node-and-corridor strategy is also an effective way to shed troublesome or expensive loci, just as it is an efficient way to acquire and connect zones of desired resources. Expanding states may not be able to consistently overcome nearby adversaries or incorporate strong competitors in a single generation, meaning that zones of potential expansion or connection would have to be part of a longer-term approach. Even permanent fragmentation could be a competent management strategy, enabling central authorities to balance groups against one another and avoid the creation of a rival power base that could be used to challenge state authority [66, p 307]. Intentional fragmentation as a key component of flexible management strategies would have had other significant benefits, because incipient states that locked themselves into a boundary might suffer additional stresses beyond the need for perimeter maintenance. Kruuk and Macdonald [67, p 528, citing Van Schantz, 1984] have proposed that for animals that occupy and defend the smallest economically viable area, one disadvantage is that "premature adjustment of territory size to short-term changes in food availability is the increased future likelihood of dangerous, escalating territorial conflicts." In other words, firm boundaries not only entail the cost of maintenance and information gathering, but also constrain opportunities for expansion in times of need.

Nascent political centers supplied by a consciously unbounded or porous hinterland could mitigate fluctuations in resource availability simply by expanding their networks of contact through previously unused nodes, even if those nodes were also used by another polity. Fluctuation in resources such as agricultural products should not be underestimated, because they would have been due not only to alterations in productivity from natural causes, but also from new inputs of technology that may have enabled significantly larger yields or occasionally caused complete resource failures. Nonexclusive territories may therefore have comprised an important mechanism of flexibility for early states. If the goal of a central authority is to extend control and extract resources and if boundary maintenance causes a disproportionate expenditure of those resources, then we would expect to see neighboring state-level societies with interdigitated fringes in which each center extracted resources from the same zone. As long as those extractions occurred sequentially (rather than simultaneously), the potential for conflict between centers would be low.

Archaeological and textual data enable us to demonstrate the dynamic process of state formation utilizing the two territorial principles of resource capture and selective 
boundary defense [11]. For example, the Sassanians of the 3-7th centuries $\mathrm{AD}$ interdigitated with the eastern Roman empire, in which key trading towns were the subject of conquest and exploitation by both sides. The Sassanians also enforced boundaries and constructed links in the form of canals, but only at select locations of investment and competition [68-70]. The Romans themselves built palisades, fences, and walls, but only at a few locations along their vast Mediterranean perimeter: facing the powerful Germanic chiefdoms, at the northern frontier of England, and in the Numidia region of North Africa. As Luttwak [71, p 68] explains, these linear barriers were designed to make an effective use of surveillance personnel, but were not a literal "border" beyond which there was no Roman presence (see also [72]). For the Aztecs, competition with the Tarascan state for mineral resources resulted in the construction of a parallel series of fortified citadels between the two centers of power [73, p 87]. The boundary was politically solid but economically porous: although it was defended through frequent military action, it was apparently permeable to economic transactions as judged by the quantity of goods that flowed through the border region [73].

\section{DISCUSSION}

A node-and-corridor model describes the flexibility in resource management that characterizes the way in which states successfully manage a highly variable economic and social landscape (e.g., [66, 74]). Leaders of expanding complex societies generally extend their control over the most important resources first, leaving some areas out of control or even out of contact (a situation that persists even in modern nation-states with regard to pastoral or nomadic populations, for example). State leaders' use of sub-par zones as corridors result in the distribution of colonized entities in which distance is maintained over water, as well as those maintained through land routes. The realities of state-level expansion mean that firm boundaries are not the goal as much as the control of resources represented by nodes. As a result, state-level attempts at node control can be highly flexible, employing strategies of alliance, coercion, and cooption in which cooperative nodes are rewarded and recalcitrant nodes warned or punished (e.g., [75]). Over time, a single location's relations to the central authority might also be highly variable, as local circumstances and central demands are realigned in succeeding generations so that nodes once treated favorably might see their status and fortunes altered.

The notion of boundaries in the expansion of complex societies also can be revised in view of the biological model. Renewed interest in ancient warfare has resulted in numerous recent works on the archaeology of conflict (e.g., [76-80]). More sophisticated analyses of contact and conflict are now made possible by larger and more comprehensive archaeological data sets that include excavated materials as well as archaeological survey in the hinterlands of prominent centers (cf. [15]). Archaeological evidence indicates that warfare and conflict in premodern societies appears for the most part to have been limited and sporadic, rather than being the allencompassing effort denoted in the ancient textual sources that celebrate military prowess. Although there are spectacular examples of violence seen in skeletal data and destruction levels, archaeological finds indicate a considerable emphasis on defense, posturing, and threats as forms of labor investment to deter violence. There is also abundant evidence for the rewards of alliance and subordination, especially in the form of iconography and exotic goods.

As paralleled in the boundary-making behavior seen in other biological systems, state-level investments were particularly undertaken at points of conflict rather than as uniform boundaries. The judicious selection and management of borders is evident even for the largest, most militant ancient states; the Romans and Aztecs, for example, had perimeters that were formally marked only in a few areas. For smaller polities, alliances at key points rather than linear features served to establish delimitations between groups. Golden's [81] study of the Maya region examines the case of La Pasadita, a settlement that was located on the only overland access routes between the rival centers of Yaxchilán and Piedras Negras and the focus of investment by both centers. Their rivalry was marked by a variety of interactions besides conflict, because "Inscriptions on monuments from both sites record the history of marriages, royal and noble visitations, and warfare events that bound the centers of the Usumacinta together in a dynamic process of political interaction" [81, p 35]. Warfare in the region was seen as only one of the ways in which rivalry could be expressed, but the value of warfare as a definitive political strategy echoes the long-term strategy of rival conspecifics in the biological realm: as Golden [81, p 45] notes, "All-out destruction of the enemy may be expensive in the short term but reduce the need for warfare in the long term by eliminating threats to royal power."

\section{CONCLUSION}

Landscape strategies are more correctly described through network models than through the prevailing view of territories as singular, homogenous entities. The biological model of networks shows how investment in "territories" is selective, strategic, and dynamic. The model has two components: first, networks of interaction consist of resource nodes that are joined by formal or informal corridors in which connections are flexible and frequently subject to change due to environmental shifts or competition. Second, territorial boundaries are situational and subject to differential energy expenditure depending on the presence and strength of competitors.

A decade ago, Gorenflo and Bell [82, p 96] proposed that the "study of networks, of a discrete as opposed to continuous representation of space, provides a more realistic 
means of studying regional systems." What we lacked was a model that illustrated how and why territories are really not bounded, blobby spaces, but networks of resources and routes than can be linked together. The biological examination of landscape use provides a stark depiction of the enormous percentage of "territory" that may not actually be utilized and why successful management of resources is most accurately analyzed and depicted by a spiky nodeand-corridor model.

\section{ACKNOWLEDGMENTS}

I thank Jeff Brantingham, Winifred Creamer, Antonio Gilman, Allen Johnson, Jerry Moore, and an anonymous reviewer for their thoughtful comments that have served to improve the manuscript. The research in this article was made possible in part by the Department of Anthropology and the Faculty of Letters and Science, UCLA. Portions of this paper were presented at the 2002 American Anthropological Association meetings in New Orleans.

\section{REFERENCES}

1. Anderson, B.R.O'G. Imagined Communities: Reflections on the Origins and Spread of Nationalism; Verso: London, 1983.

2. Murphy, A. The sovereign state system as politico-territorial ideal: Historical and contemporary considerations. In: State Sovereignty as Social Construct; Biersteker, T.J., Weber, C., Eds.; Cambridge University Press: Cambridge, 1996; pp 81-120.

3. Murphy, A. National claims to territory in the modern state system: Geographical considerations. Geopolitics 2002, 7(2), $193-214$.

4. Schofield, R. The last missing fence in the desert: The Saudi-Yemeni boundary. Geopolitics Int Boundaries 1996, 1(3), $247-299$.

5. Guentcheva, R. Symbolic geography of language: Orthographic debates in Bulgaria (1880s-today). Language Commun 1999, 19(4), 355-371.

6. Honey, R.D. Nested identities in Nigeria. In: Nested Identities: Nationalism, Territory, and Scale; Guntram, H.H., Kaplan, D.H., Eds.; Rowman and Littlefield: Lanham, MA, 1999; pp 175-197.

7. Howell, D.L. Territoriality and collective identity in Tokugawa Japan. In: Public Spheres and Collective Identities; Eisenstadt, S.N., Schluchter, W., Wittrock, B., Eds.; Transaction: New Brunswick, NJ, 2001; pp 105-132.

8. Peckham, R.S. Map mania: Nationalism and the politics of place in Greece, 1870-1922. Polit Geog 2000, 19, 77-95.

9. Smith, D.M. Introduction: The sharing and dividing of geographic space. In: Shared Space: Divided Space: Essays on Conflict and Territorial Organization; Chisholm, M., Smith, D.M., Eds.; Unwin Hyman: London, 1990; pp 1-21.

10. Tronvoll, K. Borders of Violence-Boundaries of identity: demarcating the Eritrean nation-state. Ethnic Racial Studies 1999, 22(6), 1037-1060.

11. Smith, M.L. Networks, territories and the cartography of ancient states. Ann Assoc Am Geographers 2005, 95(4), 832-849.

12. Kohler, T.A. News from the Northern American Southwest: Prehistory on the Edge of Chaos; Santa Fe Institute Working Paper 93-04-021, 1993.

13. Cowgill, G.L. Origins and development of urbanism: Archaeological perspectives. Annu Rev Anthropol 2004, 33, 525-549.

14. Carneiro, R.L. The transition from quantity to quality: A neglected causal mechanism in accounting for social evolution. Proc Natl Acad Sci USA 2000, 97(23), 12916-12931.

15. Adams, R.McC. Complexity in archaic states. J Anthropolog Archaeol 2001, 20, 345-360.

16. Cherry, J.F. Power in space: Archaeological and geographical studies of the state. In: Landscape and Culture: Geographical and Archaeological Perspectives; Wagstaff, J.M., Ed.; Basil Blackwell: Oxford, 1987; pp 146-172.

17. Johnson, G. Aspects of regional analysis in archaeology. Ann Rev Anthropol 1977, 6, 479-508.

18. Wolff, J.0. Behavioral model systems. In: Landscape Ecology of Small Mammals; Barrett, G.W., Peles, J.D., Eds.; Springer: New York, 1999 ; pp 11-40.

19. Adams, E.S. Approaches to the study of territory size and shape. Ann Rev Ecol Systematics 2001, 32, 277-303.

20. Brashares, J.S.; Archese, P. Scent marking in a territorial African antelope: I. The maintenance of borders between male oribi. Anim Behav 1999, 57, 1-10.

21. Funston, P.J.; Mills, M.G.L.; Biggs, H.C.; Richardson, P.R.K. Hunting by male lions: Ecological influences and socioecological implications. Anim Behav 1998, $56,1333-1345$.

22. Molles, L.E.; Vehrencamp, S.L. Neighbour recognition by resident males in the banded wren, Thryothorus pleurostictus, a tropical songbird with high song type sharing. Anim Behav 2001, 61(1), 119-127.

23. Palomares, F. Vegetation structure and prey abundance requirements of the Iberian lynx: Implications for the design of reserves and corridors. J Appl Ecol 2001, 38, 9-18.

24. Robichaud, I.; Villard, M.-A.; Machtans, C.S. Effects of forest regeneration on songbird movements in a managed forest landscape of Alberta, Canada. Landscape Ecol 2002, 17, 247-262.

25. Schülke, 0.; Kappeler, P.M. So near and yet so far: territorial pairs but low cohesion between pair partners in a nocturnal lemur, Phaner furcifer. Anim Behav 2003, 65(2), 331-343.

26. Carr, G.M.; Macdonald, D.W. The sociality of solitary foragers: A model based on resource dispersion. Anim Behav 1986, 34, 1540-1549.

27. Stamps, J.A. Territorial behavior: Testing the assumptions. Adv Study Behav 1994, 23, 173-232.

28. Simberloff, D.; Farr, J.A.; Cox, J.; Mehlman, D.W. Movement corridors: Conservation bargains or poor investments? Conservation Biol 1992, 6(4), 493-504.

29. Dobson, A.P.; Rodriguez, J.P. Discipline of conservation biology. In: Levin, S.A., Ed.; Encyclopedia of Biodiversity, Vol. I; Academic Press: San Diego, 2001; pp 855-864.

30. Forman, R.T.T.Landscape corridors: From theoretical foundations to public policy. In: Nature Conservation 2: The role of corridors; Saunders, D.A., Hobbs, R.J., Eds.; Surrey Beatty and Son: Chipping Norton, Australia, 1991; pp 71-84.

31. Hudgens, B.R., Haddad, N.M. Predicting which species will benefit from corridors in fragmented landscapes from population growth models. Am Nat 2003, 161(5), 808-820.

32. Soulé, M.E.; Gilpin, M.E. The theory of wildlife corridor capability. In: Nature Conservation 2: The role of Corridors; Saunders, D.A., Hobbs, R.J., Eds.; Surrey Beatty and Son: Chipping Norton, Australia, 1991; pp 3-8.

33. Stoltzenburg, W. Missing links: Connecting islands of wild land for California's roaming carnivores. Nature Conservancy 2002, Spring, 10.

34. Tigas, L.A.; Van Vuren, D.H.; Saufajot, R.M. Behavioral responses of bobcats and coyotes to habitat fragmentation and corridors in an urban environment. Biol Conserv 2002, 108, 299-306. 
35. Lincoln, R.J.; Boxshall, G.A.; Clark, P.F. A Dictionary of Ecology, Evolution and Systematics. Cambridge University Press: Cambridge, 1982.

36. Stamps, J.A.; Krishnan, V.V. Functions of fights in territory establishment. Am Nat 1997, 150(3), 393-405.

37. Stamps, J.A.; Krishnan, V.V. Territory Acquisition in Lizards: I. First encounters. Anim Behav 1994, 47(6), 1375-1385.

38. Stamps, J.A.; Krishnan, V.V. Territory acquisition in lizards: II. Establishing social and spatial relationships. Anim Behav 1994, 47(6), 1387-1400.

39. Stamps, J.A.; Krishnan, V.V. Territory acquisition in lizards: III. Competing for space. Anim Behav 1995, 49(3), 679-693.

40. Stamps, J.A.; Krishnan, V.V. Territory acquisition in lizards IV: Obtaining high status and exclusive home ranges. Anim Behav 1998, 55(2), 461-472.

41. Keeley, E.R. An experimental analysis of territory size in juvenile steelhead trout. Anim Behav 2000, 59(3), 477-490.

42. Adams, E.S. Experimental analysis of territory size in a population of the fire ant Solenopsis invicta. Behav Ecol 2003, 14(1), 48-53.

43. Grosby, S. Territoriality: the transcendental, primordial feature of modern societies. Nations Nationalism 1995, 1(2), $143-162$.

44. Lundberg, G.A.; Lawsing, M. The sociography of some community relations. Am Sociol Rev 1937, 2(3), 318-335.

45. Mitchell, J.C. The concept and use of social networks. In: Social Networks in Urban Situations: Analyses of Personal Relationships in Central African Towns; Mitchell, J.C., Ed.; Manchester University Press: Manchester, 1969; pp 1-50.

46. Cox, S.J.; Sluckin, T.J.; Steele, J. Group size, memory, and interaction rate in the evolution of cooperation. Curr Anthropol 1999, 40(3), 369-377.

47. Kochen, M., Ed. The Small World; Ablex, Norwood, NJ, 1989.

48. Dodds, P.S.; Muhamad, R.; Watts, D.J. An experimental study of search in global social networks. Science 2003, 301, 827-829.

49. Turner, M.D. The role of social networks, indefinite boundaries and political bargaining in maintaining the ecological and economic resilience of the transhumance systems of Sudano-Sahelian West Africa. In: Managing Mobility in African Rangelands: The Legitimization of Transhumance; Niamir-Fuller, M., Ed.; Intermediate Technology Publications: London, 1999; pp 97-123.

50. Fernández-Giménez, M.E. Spatial and social boundaries and the paradox of pastoral land tenure: A case study from postsocialist Mongolia. Human Ecol 2002, 30(1), 49-78.

51. Okoth-Ogendo, H.W.0. Some issues of theory in the study of tenure relations in African agriculture. Africa 1989, 59, 6-17.

52. Berry, S. Access, control and use of resources in African agriculture: An introduction. Africa 1989, 59, 1-5.

53. Ames, K.M. The Northwest coast: Complex hunter-gatherers, ecology and social evolution. Ann Rev Anthropol 1994, 23, $209-229$.

54. Kennett, D.J.; Kennett, J.P. Competitive and cooperative responses to climatic instability in coastal southern California. Am Antiquity 2000, 65(2), 379-395.

55. Service, E.R. Primitive Social Organization; Random House: New York, 1962.

56. Brun, P. From chiefdom to state organization in Celtic Europe. In: Celtic Chiefdom; Arnold B, Gilbson, D.B., Eds.; Celtic State. Cambridge University Press: Cambridge, 1995; pp 13-25.

57. Dodgshon, R.A. Modelling chiefdoms in the Scottish Highlands and islands prior the '45. In: Celtic Chiefdom; Arnold B, Gilbson, D.B., Eds.; Celtic State. Cambridge University Press: Cambridge, 1995; pp 99-109.

58. Beck, R.A., Jr. Consolidation and hierarchy: Chiefdom variability in the Mississippian Southeast. Am Antiquity 2003, 68(4), 641-661.

59. Flannery, K.V. The cultural evolution of civilizations. Ann Rev Ecol Systematics 1972, 3, 399-426.

60. Wright, H.T. The evolution of civilizations. In: American Archaeology Past and Future; Meltzer, D., Fowler, D., Sabloff, J., Eds.; Smithsonian Institution Press: Washington, DC, 1986; pp 323-68.

61. Spencer, C.S. Evolutionary approaches in archaeology. J Archaeolog Res 1997, 5(3), 209-64.

62. Feinman, G.M.; Marcus, J., Eds. Archaic States; School of American Research: Santa Fe, NM, 1998.

63. Wright, H.T. Recent research on the origin of the state. Ann Rev Anthropol 1977, 6, 379-397.

64. Cohen, R. Introduction. In: Origins of the State: The Anthropol of Political Evolution; Cohen, R., Service, E.R., Eds.; Institute for the Study of Human Issues: Philadelphia, 1978; pp 1-20.

65. Gehring, T.M.; Swihart, R.K. Body size, niche breadth, and ecologically scaled responses to habitat fragmentation: Mammalian predators in an agricultural landscape. Biol Conserv 2003, 109, 283-295.

66. Morris, C. Inka strategies of incorporation and governance. In: Archaic States; Feinman, G.M., Marcus J., Eds.; School of American Research: Santa Fe, NM, 1998; pp 293-309.

67. Kruuk, H.; Macdonald, D. Group territories of carnivores: Empires and enclaves. In: Behavioural Ecology: Ecological Consequences of Adaptive Behaviour; Sibly, R.M., Smith, R.H., Eds.; Blackwell: Oxford, 1985; pp 521-536.

68. Adams, R.McC., Nissen, H.J. The Uruk countryside: The natural setting of urban societies; University of Chicago: Chicago, 1972.

69. Howard-Johnston, J. The two great powers in late antiquity: A comparison. In: The Byzantine and Early Islamic Near East III: States, Resources and Armies; Cameron, A., Ed.; Darwin Press: Princeton, NJ, 1995; pp 157-226.

70. Simpson, St.J. Review of David Nicolle's Sassanian armies: The Iranian empire, early 3rd to mid 7th centuries AD. Antiquity 1997, 71, 242-246.

71. Luttwak, E.N. The Grand Strategy of the Roman Empire; Johns Hopkins: Baltimore, MD, 1976.

72. Trousset, P. La frontiére romaine et ses contradictions. In: La Frontière; Roman, Y., Ed.; Maison de l'Orient Méditerranéen: Lyon, 1993; pp 25-33.é

73. Pollard, H.P.; Smith, M.E. The Aztec/Tarascan border. In: The Postclassic Mesoamerican World; Smith, M.E; Berdan F.F., Eds.; University of Utah Press: Salt Lake City, 2003; pp 87-90.

74. Frye, R.N. The political history of Iran under the Sasanians. In: The Cambridge History of Iran 3(1); Yarshater, E., Ed.; Cambridge University Press: Cambridge, 1983; pp $116-180$.

75. Porter, B.N. The importance of place: Esarhaddon's stelae at Til Barsip and Sam'al. In: Historiography in the Cuneiform World; Abusch, T., Beaulieu, P.A., Huehnergard, J., Machinist, P., Steinkeller, P., Eds.; CDL Press: Bethesda, MD, 2001; pp 373-390.

76. Arkush, E.; Allen, M. The Archaeology of Warfare; University Press of Florida: Gainesville, 2006.

77. Arkush, E.; Stanish, C. Interpreting Conflict in the Ancient Andes: Implications for the Archaeology of Warfare. Curr Anthropol 2005, 46(1):3-17.

78. Brown, M.K.; Stanton, T.W., Eds.; Ancient Mesoamerican Warfare; Altamira: Walnut Creek, CA, 2003.

79. Gilchrist, R.A., Ed.; The archaeology of warfare. Theme issue of World Archaeology 2003, 35(1).

80. LeBlanc, S.A.; Register, K.E. Constant Battles: The Myth of the Peaceful, Noble Savage. St. Martin's: New York, 2003.

81. Golden, C.W. The politics of warfare in the Usumacinta Basin: La Pasadita and the realm of Bird Jaguar. In: Ancient Mesoamerican Warfare; Brown, M.K., Stanton, T.W., Eds.; Altamira: Walnut Creek, CA, 2003; pp 31-48.

82. Gorenflo, L.J.; Bell, T.L. Network analysis and the study of past regional organization. In: Ancient Road Networks and Settlement Hierarchies in the New World; Trombold, C.D., Ed.; Cambridge University Press: Cambridge, 1991; pp 80-98. 